Volume 10, Nomor 2, November 2018, pp 231-240 Copyright (c) 2017 Jurnal Akuntansi Maranatha, Program Studi Akuntansi, Fakultas Ekonomi, Universitas Kristen Maranatha. ISSN 2085-8698 | e-ISSN 2598-4977. http://journal.maranatha.edu

\title{
Pengaruh Free Cash Flow Dan Economic Value Added Terhadap Return Saham (Studi pada Saham Perusahaan yang Tercatat Aktif dalam LQ 45 di BEI Periode 2015-2017)
}

\author{
Fedro Christian Montoliang \\ Fakultas Ekonomi Program Studi Akuntansi-Univ.Kristen Maranatha \\ (Jl. Prof. Drg. Suria Sumantri No. 65, Bandung) \\ fedrochristian@gmail.com \\ Lauw Tjun Tjun \\ Fakultas Ekonomi Program Studi Akuntansi-Univ.Kristen Maranatha \\ (Jl. Prof. Drg. Suria Sumantri No. 65, Bandung) \\ lauwtjuntjun@gmail.com
}

\begin{abstract}
This study aims to analyze the effect of free cash flow and economic value added on stock returns. The type of data used is primary data and secondary data. The sample used is a company that is listed active in LQ 45 in BEI Period 2015-2017. Methods of data analysis using multiple regression analysis. Data processing is done by using SPSS Version 20 for windows. The results showed that there is a significant effect between free cash flow with stock return, there is a significant influence between economic value added with stock return, and there is significant influence between free cash flow and economic value added simultaneously with stock return.
\end{abstract}

Keywords: Economic Value Added, Free Cash Flow, Stock Return, and Stock

\section{Pendahuluan}

Pasar modal merupakan sarana yang digunakan untuk menyalurkan dananya yang bersumber dari masyarakat ke berbagai sektor untuk melaksanakan aktivitas investasinya dalam bentuk suratsurat berharga. Salah satu jenis investasi surat berharga adalah saham. Tujuan investor berinvestasi di pasar modal adalah untuk mendapatkan return. Return saham merupakan tingkat pendapatan yang diperoleh dengan mengurangkan harga penutupan saham saat ini dengan harga penutupan saham sebelumnya kemudian dibagi dengan harga penutupan tahun sebelumnya. Namun mendapatkan return atas investasi dalam pasar modal tidaklah 
begitu mudah, karena risikonya yang setara dengan keuntungan (return) yang akan didapat. Hal ini dikarenakan keuntungan yang didapat dari investasi ini berbanding lurus dengan risiko yang akan diterima. Semakin besar keuntungannya, maka semakin besar pula risiko yang akan ditanggung investor. Oleh karena itulah rasa aman melakukan investasi ini sangat diperlukan. Agar investor merasa aman untuk berinvestasi, investor harus bisa mengukur risiko serta memperkirakan pendapatan yang akan diperolehnya. (Putriani dan Sukartha, 2014).

Adanya situasi ketidakpastian yang disebabkan oleh harga saham yang dapat berubah-ubah sewaktu-waktu, menyebabkan para investor harus mampu menganalisis perubahan sahamnya dengan baik. Penelitian ini menggunakan arus kas bebas dan laba bersih sebagai variabel yang memengaruhi return saham. Arus kas bebas dipilih karena arus kas bebas merupakan parameter untuk meneliti fleksibilitas suatu emiten.Informasi mengenai arus kas suatu perusahaan, terutama arus kas dari aktivitas operasi mampu mengukur fleksibiltas keuangan suatu perusahaan.Perusahaan akhir-akhir ini cenderung menggunakan arus kas bebas sebagai parameter dalam mengukur nilai perusahaan dan pemegang saham, hal ini dikarenakan arus kas bebas tersebut dipandang lebih transparan serta lebih sulit untuk direkayasa (Putriani dan Sukartha, 2014).

Selama beberapa tahun terakhir berkembang suatu pendekatan dalam mengukur kinerja perusahaan yang dikenal dengan pendekatan nilai tambah ekonomis (Economic Value Added) atau lebih dikenal dengan sebutan EVA.Dalam hal investasi, EVA mampu mendorong manajer berpikir untuk memilih investasi yang memaksimumkan pengembalian dengan biaya modal yang minimum sehingga nilai perusahaan bisa ditingkatkan.Selain itu, faktor biaya modal yang terdapat dalam EVA mendorong manajer untuk berhati-hati dalam menentukan kebijakan struktur modal perusahaannya.Dengan penghitungan EVA diharapkan dapat memperoleh hasil perhitungan pada upaya penciptaan nilai perusahaan yang lebih realistis.( Pinangkaan, 2012).

EVA merupakan indikator tentang adanya perubahan nilai dari suatu investasi. EVA mengukur nilai tambah yang dihasilkan suatu perusahaan dengan cara mengurangi biaya modal yang timbul sebagai akibat investasi yang dilakukan. EVA yang positif menunjukkan perusahaan berhasil meningkatkan nilai perusahaan bagi pemilik perusahaan karena perusahaan mampu menghasilkan tingkat pengembalian yang melebihi tingkat biaya modalnya.Hal ini sejalan dengan tujuan manajemen keuangan yaitu memaksimumkan nilai perusahaan.Sebaliknya, EVA yang negatif menunjukkan nilai perusahaan menurun karena tingkat pengembalian lebih rendah dari biaya modal. (Nugroho dan Sarsiti, 2015).

Return saham merupakan tujuan utama seorang investor dalam berinvestasi yaitu untuk mendapatkan keuntungan dari investasinya tersebut. Investor yang melakukan investasi dalam bentuk saham akan selalu memperhitungkan hasil atas Return yang diperolehnya. Investor tersebut akan memperoleh dua bentuk hasil dari investasi saham yang berupa dividen dan capital gain. (Pinangkaan, 2012).

\section{Menurut Hartono}

returnsaham adalah tingkat pengembalian saham atas investasi yang dilakukan oleh investor. Dalam penelitian ini return saham yang digunakan adalah capital gain (loss). Capital gain (loss) merupakan selisih laba/rugi dari harga investasi sekarang relatif dengan harga perioda yang lalu.Jika harga investasi sekarang lebih tinggi dari harga investasi perioda lalu ini berarti terjadi keuntungan modal (capital gain), jika harga investasi sekarang lebih rendah dari harga investasi periode lalu maka terjadi kerugian modal (capital loss). 


\section{Kerangka Teoritis dan Hipotesis}

\section{Free Cash Flow}

Brigham dan Houston (2006:65) mengatakan bahwa arus kas bebas adalah arus kas yang benar-benar tersedia untuk didistribusikan kepada seluruh investor (pemegang saham dan pemilik utang) setelah perusahaan menempatkan seluruh investasinya pada aktiva tetap, produkproduk baru, dan modal kerja yang dibutuhkan untuk mempertahankan operasi yang sedang berjalan).

Jensen (1986) mendefinisikan free cash flow adalah aliran kas yang merupakan sisa dari pendanaan seluruh proyek yang menghasilkan net presentvalue (NPV) positif yang didiskontokan pada tingkat biaya modal yang relevan. Free cash flow ini lah yang sering menjadi pemicu timbulnya perbedaan kepentingan antara pemegang saham dan manajer.

White et al (2003) mendefinisikan free cash flow sebagai aliran kas diskresioner yang tersedia bagi perusahaan. Free cash flow adalah kas dari aktivitas operasi dikurangi capital expenditures yang dibelanjakan perusahaan untuk memenuhi kapasitas produksi saat ini. Free cash flow dapat digunakan untuk penggunaan diskresioner seperti akuisisi dan pembelanjaan modal dengan orientasi pertumbuhan (growth-oriented), pembayaran hutang, dan pembayaran kepada pemegang saham baik dalam bentuk dividen. Semakin besar free cashflow yang tersedia dalam suatu perusahaan, maka semakin sehat perusahaan tersebut karena memiliki kas yang tersedia untuk pertumbuhan, pembayaran hutang, dan dividen.

\section{Economic Value Added}

Economic Value Added (EVA) yang positif menandakan perusahaan berhasil menciptakan nilai bagi pemilik modal karena perusahaan mampu menghasilkan tingkat pengembalian yang melebihi tingkat
modalnya.Hal ini sejalan dengan tujuan untuk memaksimumkan nilai perusahaan.Sebaliknya Economic Value Added (EVA) yang negatif menunjukkan bahwa nilai perusahaan menurun karena tingkat pengembalian lebih rendah dari biaya modal (Utama 1997).

Menurut Widayanto (1993) secara sederhana apabila EVA $>0$ maka telah terjadi proses nilai tambah pada perusahaan. Sementara apabila EVA=0 menunjukkan posisi impas perusahaan. Sebaliknya apabila EVA<0 maka menunjukkan tidak terjadinya proses nilai tambah pada perusahaan, karena laba yang tersedia tidak bisa memenuhi harapan para penyandang dana.

Menurut Lisa (1999) EVA adalah ukuran nilai tambah ekonomis yang dihasilkan perusahaan sebagai akibat dari aktivitas atau strategi manajemen.EVA yang positif menandakan perusahaan berhasil menciptakan nilai bagi pemilik modal karena perusahaan mampu menghasilkan tingkat penghasilan melebihi tingkat biaya modal.Hal ini sejalan dengan tujuan untuk memaksimalkan nilai perusahaan.Sebaliknya EVA yang negatif menunjukkan bahwa nilai perusahaan menurun karena tingkat pengembalian lebih rendah daripada biaya modalnya.

\section{Return Saham}

Return adalah tingkat pengembalian yang dinikmati oleh investor dari kelebihan investasi yang dilakukan. Tanpa adanya keuntungan yang dapat dinikmati dari suatu investasi tentunya investor tidak akan mau berinvestasi. Return saham merupakan salah satu faktor yang memotivasi investor berinvestasi dan juga merupakan imbalan atas keberanian investor menanggung risiko atas investasi yang dilakukannya. Return saham merupakan selisih antara harga jual atau harga saat ini, dengan harga pembelian atau harga awal periode (Husnan, 1994).

Return (kembalian) adalah tingkat keuntungan yang dinikmati oleh pemodal 
atas suatu investasi yang dilakukan (Ang, 1997).

Menurut Hartono (2008) returnsaham adalah tingkat pengembalian saham atas investasi yang dilakukan oleh investor. Dalam penelitian ini return saham yang digunakan adalah capital gain (loss). Capital gain (loss) merupakan selisih laba/rugi dari harga investasi sekarang relatif dengan harga perioda yang lalu.Jika harga investasi sekarang lebih tinggi dari harga investasi perioda lalu ini berarti terjadi keuntungan modal (capital gain), jika harga investasi sekarang lebih rendah dari harga investasi perioda lalu maka terjadi kerugian modal (capital loss).

\section{Model Penelitian Dan Pengembangan Hipotesis}

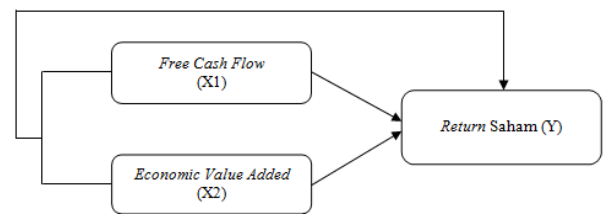

\section{Gambar 1 Model Penelitian}

H1 : Free cash flow memiliki pengaruh yang positif terhadap return saham

$\mathrm{H} 2$ : Economic value added memiliki pengaruh yang positif terhadap return saham

H3 : Free cash flow dan economic value added memiliki pengaruh yang positif terhadap return saham.

\section{Metode Penelitian}

\section{Jenis Penelitian}

Metode dalam penelitian ini adalah Causal Explanatory. Explanatory research adalah penelitian yang bertujuan menjelaskan hubungan antar variabel dan fenomena penelitian (Cooper \& Schindler, 2011). Sementara, Causal merupkan hubungan sebab akibat yang dimiliki oleh dia atau lebih variabel. Dengan demikin causal expalantory adalah hubungan antara variabel dan pengujian hipotesis yang telah dirumuskan sebelumnya dan bertujuan untuk menjelaskan berbagai kejadian dan fenomena penelitian.Menurut Suliyanto (2006:11) riset kausal adalah riset yang bertujuan mengetahui pengaruh antar variabel.Sedangkan menurut Hartono (2013:13) riset explanatory adalah riset yang mencoba menjelaskan fenomena yang ada.

Dalam analisis dan pengolahan data, penelitian ini merupakan penelitian yang bersifat kontributif, dimana tujuan dari penelitian ini adalah melihat adanya kontribusi (pengaruh) antara variabelvariabel yang diteliti.

\section{Populasi dan Sampel}

Populasi dalam penelitian ini adalah seluruh perusahaan yang masuk dalam LQ45dan terdaftar di Bursa Efek Indonesia.Sampel yang digunakan dalam penelitian ini diambil dengan menggunakan pendekatan nonprobability sampling, yaitu teknik pengambilan sampel yang tidak memberi peluang/kesempatan sama bagi setiap unsur atau anggota populasi untuk dipilih menjadi sampel (Sugiyono, 2012, 120), dan dengan metode purposive sampling. Purposive sampling adalah teknik penentuan sampel dengan menggunakan kriteria atau pertimbangan tertentu (Sugiyono, 2012, 122).

Adapun kriteria atau pertimbangan pengambilan sampel yang digunakan penulis adalah:

1. Perusahaan telah terdaftar di Bursa Efek Indonesia (BEI)

2. Tidak delisting selama periode pengamatan tahun

3. Memberikan laporan keuangan secara periodik kepada Bursa Efek Indonesia dan dipubikasikan di website resmi BEI.

4. Perusahaan menyediakan data yang lengkap, sesuai dengan yang dibutuhkan dalam penelitian ini. 


\section{Teknik Pengumpulan Data}

Dalam penelitian ini, penulis mengumpulkan data yang dibutuhkan dengan menggunakan teknik sebagai berikut:

1. Penelitian Lapangan

Dalam penelitian ini, penulis melakukan observasi pada obyek penelitian dengan tujuan untuk memperoleh data sekunder, yaitu dengan melakukan penelitian pada situs resmi Bursa Efek Indonesia yang beralamat di www.idx.co.id.

2. Studi Pustaka

Dalam penelitian ini, penulis melakukan studi kepustakaan dengan cara mempelajari, mengkaji dan menelaah literatur-literatur berupa buku, jurnal, berita, dan artikel blog di internet yang ada kaitanya dengan masalah yang diteliti.

\section{Hasil Penelitian dan Pembahasan}

\section{Uji Hipotesis}

Dalam penelitian ini, peneliti melakukan uji hipotesis dengan taraf kepercayaan 95\%, dengan syarat sebagai berikut:

1. Tolak hipotesis, jika nilai signifikansi hitung lebih besar atau sama dengan $\alpha=0.05$, yang berarti tidak terdapat pengaruh antara independen variabel terhadap dependen variabel.

2. Terima hipotesis, jika nilai signifikansi hitung lebih besar atau sama dengan $\alpha=0.05$, yang berarti terdapat pengaruh antara independen variabel terhadap dependen variabel.
Berdasakan pengolahan data, maka peneliti menemukan hasil sebagai berikut:

\section{Uji Hipotesis 1: Pengaruh antara Free Cash Flow terhadap Return Saham}

Tabel 1

Coefficients ${ }^{2}$ Hipotesis 1

\begin{tabular}{|c|c|c|c|c|c|}
\hline \multirow[t]{2}{*}{ Model } & \multicolumn{2}{|c|}{ Unstandardized Coefficients } & \multirow{2}{*}{\begin{tabular}{|c|} 
StandardizedCoefficients \\
Beta
\end{tabular}} & \multirow[t]{2}{*}{$t$} & \multirow[t]{2}{*}{ Sig. } \\
\hline & $B$ & Std. Enor & & & \\
\hline (Constant) & $.357,970$ & 388,855 & & .921 &, 359 \\
\hline Free Cash Flow & $9,169 \mathrm{E}-006$ &, 000 &, 275 & 3,304 &, 001 \\
\hline
\end{tabular}

Uji hipotesis 1, peneliti menemukan nilai signifikansi hitung sebesar 0.001, yang berarti lebih kecil dari 0.05. Dengan demikian, maka terdapat pengaruh yang signifikan antara Free Cash Flow dengan Return Sahampada perusahaan yang tercatat aktif dalam LQ 45 di Bursa Efek Indonesia periode 2015-2017.

\section{Tabel 2}

$$
\text { Model Summary }{ }^{\mathrm{b}} \text { Hipotesis } 1
$$

\begin{tabular}{|l|r|r|r|r|}
\hline Model & $R$ & R Square & AdjustedR Square & Std. Eror of the Estimate \\
\hline 1 & $.275^{\mathrm{3}}$ & .076 & .069 & 4323,71016 \\
\hline
\end{tabular}

a. Predictors: (Constant), Free Cash Flow

b. Dependent Variable: Retum Saham

Peneliti menemukan nilai 0.076 sebagai koefisien determinasi, yang berarti bahwa hanya sebesar 7,6\% dari Return sahamdipengaruhi oleh free cash flow pada perusahaan-perusahaan LQ 45 pada tahun 2015-2017. 


\section{Uji Hipotesis 2: Pengaruh antara Economy Value Added terhadap Return Saham}

\section{Tabel 3}

Coefficients ${ }^{\mathrm{a}}$ Hipotesis 2

\begin{tabular}{|c|c|c|c|c|c|}
\hline \multirow[t]{2}{*}{ Model } & \multicolumn{2}{|c|}{ Unstandardized Coefficients } & Standardized Coefficients & \multirow[t]{2}{*}{$t$} & \multirow[t]{2}{*}{ Sig. } \\
\hline & B & Std. Emor & Beta & & \\
\hline (Constant) & $.214,579$ & 182,205 & & $-1,178$ &, 241 \\
\hline Economic Value Added & 2,137E-011 &, 000 &, 883 & 21,664 &, 000 \\
\hline
\end{tabular}

Uji hipotesis 2, peneliti menemukan nilai signifikansi hitung sebesar 0.000 , yang berarti lebih kecil dari 0.05. Dengan demikian, maka terdapat pengaruh yang signifikan antara Economic Value Added dengan Return Sahampada perusahaan yang tercatat aktif dalam LQ 45 di Bursa Efek Indonesia periode 2015-2017.

\section{Tabel 4}

Model Summary ${ }^{\mathrm{b}}$ Hipotesis 2

\begin{tabular}{|l|c|r|r|r|}
\hline Model & R & R Square & Adjusted R Square & Std. Error of the Estimate \\
\hline 1 &, $883^{\mathrm{a}}$ &, 779 &, 778 & 2113,45926 \\
\hline
\end{tabular}

Peneliti menemukan nilai 0.779 sebagai koefisien determinasi, yang berarti bahwa hanya sebesar 77,9\% dari Return sahamdipengaruhi oleh Economic Value Added pada perusahaan-perusahaan LQ 45 pada tahun 2015-2017.

\section{Uji Hipotesis 3: Pengaruh simultan antara Free Cash Flow dan Economy Value Added terhadap Return Saham}

Tabel 5

ANOVA'Hipotesis 3

\begin{tabular}{|ll|r|r|r|c|c|}
\hline \multicolumn{1}{|l|}{ Model } & & Sum of Squares & \multicolumn{1}{c|}{ df } & \multicolumn{1}{c|}{ Mean Square } & F & \multicolumn{1}{c|}{ Sig. } \\
\hline \multirow{4}{*}{1} & Regression & 2098061844,239 & 2 & 1049030922,119 & 233,778 &, $000^{\circ}$ \\
& Residual & 592324171,659 & 132 & 4487304,331 & & \\
& Total & 2690386015,998 & 134 & & & \\
\hline
\end{tabular}

a. Dependent Variable: Retum Saham

b. Predictors: (Constant), Economic Value Added, Free Cash Flow

Uji hipotesis 3, peneliti menemukan nilai signifikansi hitung sebesar 0.000, yang berarti lebih kecil dari 0.05. Dengan demikian, maka terdapat pengaruh yang signifikan antara Free Cash Flow dan Economic Value Added secara simultan dengan Return Sahampada perusahaan yang tercatat aktif dalam LQ 45 di Bursa Efek Indonesia periode 2015-2017.

\section{Tabel 6}

Model Summary ${ }^{\mathrm{b}}$ Hipotesis 3

\begin{tabular}{|l|c|r|r|r|}
\hline Model & R & R Square & Adjusted R Square & Std. Error of the Estimate \\
\hline 1 &, $883^{3}$ &, 780 &, 777 & 2118,32583 \\
\hline
\end{tabular}

Peneliti menemukan nilai 0.780 sebagai koefisien determinasi, yang berarti bahwa hanya sebesar 78,0\% dari Return sahamdipengaruhi oleh Free Cash Flow dan Economic Value Added pada perusahaanperusahaan LQ 45 pada tahun 2015-2017.

\section{Pembahasan}

1. Pengaruh antara Free Cash Flow terhadap Return Saham

Brigham dan Houston (2006:65) mengatakan bahwa arus kas bebas adalah arus kas yang benar-benar tersedia untuk didistribusikan kepada seluruh investor (pemegang saham dan pemilik utang) setelah perusahaan menempatkan seluruh investasinya pada aktiva tetap, produk-produk baru, dan modal kerja yang dibutuhkan untuk mempertahankan operasi yang sedang berjalan).

Free cash flow dapat digunakan untuk penggunaan diskresioner seperti akuisisi dan pembelanjaan modal dengan orientasi pertumbuhan (growthoriented), pembayaran hutang, dan pembayaran kepada pemegang saham baik dalam bentuk dividen. Semakin besar free cashflow yang tersedia dalam suatu perusahaan, maka semakin sehat perusahaan tersebut karena memiliki kas yang tersedia untuk pertumbuhan, pembayaran hutang, dan dividen. 
Berdasakran uji hipotesis 1, terdapat pengaruh yang signifikan antara Free Cash Flow dengan Return Sahampada perusahaan yang tercatat aktif dalam LQ 45 di Bursa Efek Indonesia periode 2015-2017, dimana sebesar 7,6\% dari Return sahamdipengaruhi oleh free cash flow pada perusahaan-perusahaan LQ 45 pada tahun 2015-2017

Dengan demikian, hasil penelitian ini tidak sejalan dengan penelitian yang dilakukan oleh Ni Putu Putriani dan I Made Sukartha (2014) dengan judul penelitian " Pengaruh Arus Kas Bebas Dan Laba Bersih Pada Return Saham Perusahaan LQ-45 ", yang menunjukkan bahwa arus kas bebas tidak berpengaruh secara signifikan pada return saham.

\section{Pengaruh antara Economy Value Added terhadap Return Saham}

Menurut Lisa (1999) EVA adalah ukuran nilai tambah ekonomis yang dihasilkan perusahaan sebagai akibat dari aktivitas atau strategi manajemen.EVA yang positif menandakan perusahaan berhasil menciptakan nilai bagi pemilik modal karena perusahaan mampu menghasilkan tingkat penghasilan melebihi tingkat biaya modal.Hal ini sejalan dengan tujuan untuk memaksimalkan nilai perusahaan. Sebaliknya EVA yang negatif menunjukkan bahwa nilai perusahaan menurun karena tingkat pengembalian lebih rendah daripada biaya modalnya.

Economic Value Added (EVA) yang positif menandakan perusahaan berhasil menciptakan nilai bagi pemilik modal karena perusahaan mampu menghasilkan tingkat pengembalian yang melebihi tingkat modalnya.Hal ini sejalan dengan tujuan untuk memaksimumkan nilai perusahaan. Sebaliknya Economic Value Added (EVA) yang negatif menunjukkan bahwa nilai perusahaan menurun karena tingkat pengembalian lebih rendah dari biaya modal.

Perhitungan EVA diharapkan akan mendapatkan hasil perhitungan nilai ekonomis perusahaan yang lebih realistis. Oleh karena itu, EVA dihitung berdasarkan perhitungan biaya modal (cost of capital) yang menggunakan nilai pasar berdasarkan kepentingan kreditur terutama para pemegang saham dan bukan berdasarkan nilai buku yang bersifat histories. Perhitungan EVA juga diharapkan dapat mendukung penyajian laporan keuangan sehingga akan mempermudah bagi para pengguna laporan keuangan.

Berdasarkan uji hipotesis2, terdapat pengaruh yang signifikan antara Economic Value Added dengan Return Sahampada perusahaan yang tercatat aktif dalam LQ 45 di Bursa Efek Indonesia periode 2015-2017, ditemukan bahwa sebesar $77,9 \%$ dari Return saham dipengaruhi oleh Economic Value Added pada perusahaan-perusahaan LQ 45 pada tahun 2015-2017.

Hasil penelitian ini sejalan dengan penelitian yang dilakukan oleh Akmal Hidayat dan Siti Setyaningsih (2011) dengan judul penelitian "Pengaruh Economic Value Added, Market Share,Earnings Dan Net Cash Flow Terhadap Return Saham (Studi Pada Perusahaan Manufaktur Jenis Consummer Goods Di Bursa Efek Indonesia 2004 - 2007)", yang menunjukkan bahwa Variabel Economic Value Secara parsial Mempunyai Pengaruh Positif Terhadap Return Saham. Dengan demikian, adanya peningkatan Economic Value Added yang dimiliki oleh perusahaan memiliki kemampuan untuk dapatmeningkatkan Return Saham. 


\section{Pengaruh simultan antara Free Cash Flow dan Economy Value Added terhadap Return Saham}

Free cash flow adalah kas dari aktivitas operasi dikurangi capital expenditures yang dibelanjakan perusahaan untuk memenuhi kapasitas produksi saat ini. Free cash flow dapat digunakan untuk penggunaan diskresioner seperti akuisisi dan pembelanjaan modal dengan orientasi pertumbuhan (growthoriented), pembayaran hutang, dan pembayaran kepada pemegang saham baik dalam bentuk dividen. Semakin besar free cashflow yang tersedia dalam suatu perusahaan, maka semakin sehat perusahaan tersebut karena memiliki kas yang tersedia untuk pertumbuhan, pembayaran hutang, dan dividen.

Economic Value Added (EVA) yang positif menandakan perusahaan berhasil menciptakan nilai bagi pemilik modal karena perusahaan mampu menghasilkan tingkat pengembalian yang melebihi tingkat modalnya.Hal ini sejalan dengan tujuan untuk memaksimumkan nilai perusahaan. Sebaliknya Economic Value Added (EVA) yang negatif menunjukkan bahwa nilai perusahaan menurun karena tingkat pengembalian lebih rendah dari biaya modal.

Menurut Lisa (1999) EVA adalah ukuran nilai tambah ekonomis yang dihasilkan perusahaan sebagai akibat dari aktivitas atau strategi manajemen. EVA yang positif menandakan perusahaan berhasil menciptakan nilai bagi pemilik modal karena perusahaan mampu menghasilkan tingkat penghasilan melebihi tingkat biaya modal.Hal ini sejalan dengan tujuan untuk memaksimalkan nilai perusahaan. Sebaliknya EVA yang negatif menunjukkan bahwa nilai perusahaan menurun karena tingkat pengembalian lebih rendah daripada biaya modalnya.
Menurut Hartono (2008) return saham adalah tingkat pengembalian saham atas investasi yang dilakukan oleh investor. Dalam penelitian ini return saham yang digunakan adalah capital gain (loss). Capital gain (loss) merupakan selisih laba/rugi dari harga investasi sekarang relatif dengan harga perioda yang lalu. Jika harga investasi sekarang lebih tinggi dari harga investasi perioda lalu ini berarti terjadi keuntungan modal (capital gain), jika harga investasi sekarang lebih rendah dari harga investasi perioda lalu maka terjadi kerugian modal (capital loss).

Berdasarkan hasil uji hipotesis 3, terdapat pengaruh yang signifikan antara Free Cash Flow dan Economic Value Added secara simultan dengan Return Sahampada perusahaan yang tercatat aktif dalam LQ 45 di Bursa Efek Indonesia periode 2015-2017, dimana sebesar 78,0\% dari Return sahamdipengaruhi oleh Free Cash Flow dan Economic Value Added pada perusahaan-perusahaan LQ 45 pada tahun 2015-2017.

Dengan demikian, hasil penelitian ini sejalan dengan penelitian yang dilakukan oleh Akmal Hidayat dan Siti Setyaningsih (2011) dengan judul penelitian "Pengaruh Economic Value Added, Market Share,Earnings Dan Net Cash Flow Terhadap Return Saham (Studi Pada Perusahaan Manufaktur Jenis Consummer Goods Di Bursa Efek Indonesia 2004 - 2007)", yang menunjukkan bahwa Variabel Economic Value Added, Merket Share, Earnings Dan Net Cash Flow secara Simultan Mempunyai Pengaruh Positif Terhadap Return Saham. Dengan demikian, adanya peningkatan Free Cash Flow dan Economic Value Added secara simultan yang dimiliki oleh perusahaan memiliki kemampuan untuk dapat meningkatkan Return Saham. 


\section{Simpulan dan Saran}

\section{Simpulan}

1. Berdasarkan uji hipotesis 1 , terdapat pengaruh yang signifikan antara Free Cash Flow dengan Return Saham pada perusahaan yang tercatat aktif dalam LQ 45 di Bursa Efek Indonesia periode 2015-2017, dimana sebesar 7,6\% dari Return saham dipengaruhi oleh free cash flow pada perusahaan-perusahaan LQ 45 pada tahun 2015-2017

2. Berdasarkan uji hipotesis 2, terdapat pengaruh yang signifikan antara Economic Value Added dengan Return Sahampada perusahaan yang tercatat aktif dalam LQ 45 di Bursa Efek Indonesia periode 2015-2017, ditemukan bahwa sebesar $77,9 \%$ dari Return saham dipengaruhi oleh Economic Value Added pada perusahaan-perusahaan LQ 45 pada tahun 2015-2017

3. Berdasarkan uji hipotesis 3, terdapat pengaruh yang signifikan antara Free Cash Flow dan Economic Value Added secara simultan dengan Return Saham pada perusahaan yang tercatat aktif dalam LQ 45 di Bursa Efek Indonesia periode 2015-2017, dimana sebesar $78,0 \%$ dari Return saham Terdapat pengaruh yang dipengaruhi oleh Free Cash Flow dan Economic Value Added pada perusahaan-perusahaan LQ 45 pada tahun 2015-2017

\section{Saran}

Berdasarkan hasil penelitian, peneliti mengungkapkan saran sebagai berikut:

\section{Saran Teoretis}

a. peneliti menyarankan kepada peneliti selanjutnya untuk dapat melakukan riset mengenai variabel Free Cash Flow dan Economic Value Addedsecara simul tan dengan Return Saham pada berbagai bidang usaha lain.

b. Peneliti menyarankan kepada peneliti selanjutnya untuk dapat melakukan riset mengenai variabelvariabel lain yang dapat mempengaruhi Return Saham.

\section{Saran Praktis}

a. Berdasarkan hasil penelitian, ditemukan bahwa terdapat pengaruh yang signifikan baik secara parsial maupun simultan antara Free Cash Flow dan Economic Value Added secara simultan dengan Return Saham. Dengan demikian, baik para Free Cash Flow dan Economic Value Added dapat dijadikan sebagai indikator dari Return saham.

b. Peneliti menemukan bahwa Economic Value Added memiliki pengaruh yang lebih besar dari Free Cash Flow dalam menentukan Return Saham.

\section{Daftar Pustaka}

Abdullah, Faisal M. (2003). Manajemen Perbankan, edisi pertama. Malang: UMM Press.

Ang, Robert. (1997). Buku Pintar Pasar Modal Indonesia, Mediasoft, Indonesia.

Anthony, R. N. dan V. Govindarajan. (2002). Penerjemah F. X. Kurniawan Tjakrawala.Sistem Pengendalian Manajemen, Edisi 1. Jakarta: Salemba Empat.

Bacharuddin. (2002). EVA dan MVA sebagai Pengukur Kinerja Perusahaan.Sinergi Kajian Bisnis dan Manajemen, Vol. 5, No.1, hal.13-20.

Brigham, Eugene \& Joel Houston. (2006). Manajemen Keuangan. Edisi kesepuluh. Terjemahan Dodo Suharno, Herman Wibowo. Jakarta: Erlangga.

Cooper, Donald R. \& Schindler, Pamela S. (2011). Business research methods (11th ed.). New York: Mc GrawHill/Irwin. 
Darmadji. (2001). Pasar Modal di Indonesia: Pendekatan Tanya Jawab. Edisi Pertama. Jakarta: Salemba Empat.

Ghozali, Imam. (2009). Aplikasi Analisis Multivariate dengan Program SPSS, cetakan ke empat. Semarang: Penerbit Universitas Diponegoro.

Gitman, Lawrence. (2009). Principles of Manajerial Finance. United States: Pearson Addison Wesley.

Halim, Abdul. (2005). Analisis Investasi.Edisi Dua, hal. 34. Jakarta: Salemba Empat.

Hartono, J. (2008). Teori Portofolio dan Analisis Investasi, Edisi 5. Yogyakarta: BPFE UGM.

Hartono, Jogiyanto. (2013). Teori Portofolio dan Analisis Investasi. EdisiKedelapan. Yogyakarta: BPFE.

Husnan, Suad. (2001). Dasar-dasar Teori Portofolio dan Analisis Sekuritas. EdisiKetiga. Yogyakarta: EMP YKPN.

Iramani, R. dan Erie Febrian.(2005). Financial Value Added Suatu Paradigma Dalam Pengukuran Kinerja dan Nilai Tambah Perusahaan.Jurnal Akuntansi dan Keuangan, Vol 7, No.1 Mei 2005: 110.

Jensen, Michael C. (1986). Agency Costs of Free Cash Flow, Corporate Finance, and Takeovers.American Economic Review. May, vol. 76 (2): 323-329

Kieso, D. E., J. J. Weygandt., dan T. D. Warfield.(2007). Intermidaiate Accounting, Twelfth Edition. Asia: John Wiley and Sons.

Lisa, L. U. (1999). EVA Sebagai Ukuran Keberhasilan Kinerja Manajeman. Jurnal Akuntansi dan Keuangan, Mei,Vol. 1, No. 1, Hal. 28-42.

Nasser, E.M. (2003). Pengukuran Kinerja Perusahaan dengan Metode EVA danMVA, Media Riset Akuntansi, Auditing dan Informasi, Vol. III, No.1, April, Hlm. 24-42.
Nugroho, G.A. dan Sarsiti.(2015). Analisis Pengaruh Eva dan Mva TerhadapReturn Saham pada Perusahaan Manufaktur di Bursa Efek Indonesia. Vol. 13(No. 2).

Pinangkaan,Getereida (2012). Pengaruh Return On Investment (ROI) Dan Economic ValueAdded (EVA) Terhadap ReturnSaham Perusahaan.Jurnal Ilmiah STIE MDP. Vol. 1(No.2).

Pramono, Peni R. (2008). Menilai Kinerja Manajer Lewat Laporan Keuangan. Jakarta: PT. Gramedia.

Putriani, N.P. dan Sukartha, I.M. (2014).Pengaruh Arus Kas Bebas Dan Laba Bersih Pada ReturnSaham Perusahaan LQ-45.E-Jurnal AkuntansiUniversitas Udayana, hal. $390-401$.

Samsul, Mohamad. (2008). Pasar Modal dan Manajemen Portofolio. Jakarta: Erlangga.

Sugiyono.(2012). Metode Penelitian Bisnis. Bandung: Alfabeta.

Suliyanto.(2006). Metode Riset Bisnis. Yogyakarta: Andi.

Tandelilin, Eduardus. (2001). Analisis Investasi dan Manajemen Portofolio.Edisi pertama. Yogyakarta: BPFE.

Utama, Sidharta. (1997). Economic Value Added: Pengukur Penciptaan Nilai Perusahaan. Usahawan, No.4 Th. XXVI

White, Gerald I., Sondhi, Ashwinpul C. dan Fried, Dov. (1998). The Analysis and Use Of Financial Statements. New York: John Wiley and Sons, Inc.

Widayanto, Gatot. (1993). EVA/NITAMI Suatu Terobosan Baru dalam Pengukuran Kinerja Perusahaan. Manajemen Usahawan Indonesia, No. 4, Th. XXVI.

\section{Internet:}

www.idx.co.id. 